imposèrent au comité organisateur d'attendre que la liaison avec la colonie fût devenue plus normale. Après une série de prises de contact au cours des années i 945 et I 946 , il fut décidé que les travaux du prochain congrès seraient consacrés à l'étude de 'la question sociale indigène', et la date en fut fixée au 4 et $s$ octobre 1947 . Le congrès vient donc d'avoir lieu. A la séance inaugurale, M. le Ministre des Colonies annonça la dotation d'une somme de 2 milliards 350 millions au fonds du bien-être indigène. Ce fonds, qui permettra des dépenses annuelles d'un quart de milliard, aura pour mission d'aider matériellement, socialement et spirituellement les populations de l'intérieur; celles des centres extracoutumiers et des camps miniers étant confiées, sous la surveillance de l'État, à la responsabilité des employeurs.

Les rapports, présentés et discutés au congrès, furent l'œuvre de diverses commissions, présidées par des personnalités coloniales éminentes. Elles furent au nombre de dix, ayant respectivement comme objet: l'enseignement à tous les degrés pour indigènes, l'hygiène et la démographie, l'artisanat indigène, les cultures indigènes, les organisations sociales de chefferies, la main-d'œuvre indigène, l'organisation familiale, les évolués, le rôle social de la force publique. M. Max Horn, conseiller du gouvernement de la colonie, s'était chargé de coordonner les conclusions générales.

Nous ne pouvons songer à analyser chacun de ces rapports. Louons-en, dans l'ensemble, l'excellente venue, le sens de la réalité, le vif désir de progrès.

\title{
Institut pour la Recherche scientifique en Afrique centrale
}

PAR un arrêté en date du I juillet, x947, a été créé un institut pour la recherche scientifique en Afrique centrale, ayant pour l'objet de promouvoir, réaliser at coordonner, spécialement au Congo Belge et au Ruanda-Urundi, l'étude de l'homme et de la nature. A cette fin, il sera créé au Congo Belge et à Ruanda-Urundi un ou plusieurs centres où les chercheurs belges et étrangers pourront s'adonner à leurs études. L'Institut sera administré par un conseil composé de personnalités scientifiques belges et étrangers.

\section{Language Problems in Fundamental Education}

Nine experts (British, French, Belgian, American, Dutch, Czech) were summoned to Paris in July I 947 by U.N.E.S.C.O. to advise on the following questions : (I) How far are small tribal languages capable of serving the needs of modern education? (2) If the mother tongue must be used for the early teaching of children can a second language be taught at a later stage to break down the barriers of language difficulties? (3) How can the latest techniques of teaching languages with the aid of films and gramophone records be applied to fundamental education projects?

\section{Fundamental Education and the Use of the Cinema}

The British Film Institute organized a Conference on 'The Film in Colonial Development" on 16 January 1948. The Conference was opened by the Secretary of State for the Colonies and among the speakers was Mr. John Grierson, Director of Mass Communications in U.N.E.S.C.O. Mr. Grierson described the peoples of the world as being on the movementally and spiritually; as being in revolt against illiteracy and primitive conditions; this was a challenge to every citizen, especially to those of Great Britain (and other nations) who possessed the privilege and responsibility of governing colonial peoples. The present problem was itself the result of the world's riches and of the gap between technical invention and the knowledge of how to use it. He quoted the words of Julian Huxley: 'Man 